\title{
IDENTITAS KULTUR DALAM RELASI ETNIK KOMIN-AMBER DI PAPUA
}

\author{
${ }^{1}$ Syarifuddin, ${ }^{2}$ Sarwititi Sarwoprasodjo, ${ }^{3}$ Musa Hubeis, ${ }^{4}$ Ninuk Purnaningsih \\ ${ }^{1}$ Sekolah Pascasarjana, Institut Pertanian Bogor \\ ${ }^{2,3,4}$ Fakultas Ekologi Manusia, Institut Pertanian Bogor \\ Jl. Kamper, Babakan, Dramaga, Bogor, Jawa Barat 16680 \\ No.Telp./HP: ${ }^{1} 081248004319,{ }^{2} 08129547486,{ }^{3} 0811119424,{ }^{4} 081317095618$ \\ E-Mail: ${ }^{1}$ syarif1575@gmail.com, ${ }^{2}$ sarwititi@gmail.com, ${ }^{3}$ hubeis.musa@yahoo.com, \\ ${ }^{4}$ npurnaningsih@yahoo.com
}

Naskah diterima tanggal 11 April 2017, direvisi tanggal 1 Juni 2017, disetujui tanggal 2 Juni 2017

\section{ETHNIC IDENTITY OF CULTURE IN RELATION KOMIN-AMBER IN PAPUA}

\begin{abstract}
Identity is not just a question of the name, but what is the meaning behind the name. At least the name is an identification and identity that can show the characteristics and character. If the characteristic is inherent in an ethnic, then it becomes a marker of ethnic identity on them. The purpose of this study is to analyze and describe culture of the ethnic komin identity as indigenous peoples and ethnic amber as settler communities in the perspective of intercultural communication. The research method is designed in a mixed method that combines qualitative and quantitative methods with sequential exploratory strategies. The research was conducted in Jayapura Papua Province by using a combination of research methods (mix method), with a sample of 200 respondents and 8 Participants. The results of this study indicate Cultural identity of ethnic Komin and Amber differs significantly in terms of 1) The context of communication (high vs. low context communication context), 2) cultural orientation (individualist versus collectivist cultures). 3) Self-construal (independent vs. interdependent).
\end{abstract}

Keywords: communication style, cultural orientation, self construal.

Abstrak. Identitas bukan sekedar persoalan nama, tetapi apa makna di balik nama tersebut. Setidaknya nama merupakan tanda pengenal dan identitas yang dapat menunjukkan ciri-ciri serta karakternya. Jika ciri khas itu melekat pada suatu etnik, maka hal itu menjadi penanda jati diri pada etnik tersebut. Penelitian ini bertujuan untuk menganalisis dan mendeskripsikan identitas kultur etnik Komin sebagai masyarakat pribumi dan etnik Amber sebagai masyarakat pendatang dalam perspektif komunikasi antarbudaya. Metode penelitian dirancang dalam skema penelitian kombinasi (mixed method) yang menggabungkan metode kualitatif dan kuantitatif dengan strategi eksploratoris sekuensial. Penelitian dilaksanakan di Kota Jayapura Provinsi Papua dengan sampel 200 responden dan 8 (delapan) partisipan. Hasil penelitian menunjukkan bahwa identititas kultur pada etnik Komin dan Amber berbeda nyata dalam hal: 1) Konteks komunikasi (high context vs low context communication), 2) Orientasi budaya (individualist vs collectivist), dan 3) Self construal (Independent vs Interdependent).

Kata kunci: gaya komunikasi, orientasi budaya, makna diri. 


\section{PENDAHULUAN}

\begin{tabular}{rrrr}
\multicolumn{2}{c}{ Papua sebuah provinsi di ujung } \\
Timur Indonesia
\end{tabular} masyarakatnya yang multikultural dan multietnik. Keragaman suku, ras, budaya, bahasa, dan agama menjadikan Papua sebagai potret miniatur Indonesia sesungguhnya.

Sayangnya, keberagaman ini seringkali menimbulkan benturan di masyarakat khususnya dalam relasi sosial antaretnik. Relasi etnik di Papua khususnya etnik pribumi (Komin) dan etnik pendatang (Amber) mengalami pasang surut. Dalam situasi tertentu relasi kedua etnik berjalan harmonis, namun seketika dapat berubah menjadi benturan yang menimbulkan kerusuhan di masyarakat. Benturan keberagaman di Papua bukan hanya terjadi dalam relasi pribumi dan pendatang, tapi juga terjadi dalam skala in-group baik etnik Komin maupun Amber. Benturan yang terjadi dalam komunitas in-group, efeknya tidak terlalu berdampak bila dibandingkan benturan yang melibatkan antara etnik Komin dan Amber.

Salah satu pemicunya adalah minimnya pemahaman kedua etnik dalam menyikapi atau merespon persoalan yang muncul dalam setiap interaksi mereka sehari-hari. Perbedaan sikap dan cara pandang kedua etnik terlihat sangat dipengaruhi oleh rasa keidentitasan mereka. Persoalan yang sifatnya pribadi bisa merembet ke persoalan etnik. Kesenjangan ekonomi, pemahaman ideologi, dan kehidupan sosial budaya pun selalu dikaitkan dengan identitas etnik mereka masing-masing.

Makna identitas dalam masyarakat multikultural dan multietnik menjadi penting karena selain menjadi pembeda, identitas juga merupakan harga diri dan menjadi cerminan bagi setiap etnik dalam membangun relasi dengan etnik lainnya. Identitas yang dimaknai luas sebagai etnisitas merupakan hasil konstruksi (proses) sosial yang lazim disebut askripsi (ascription) yang berarti apa pun tandanya asal bisa dipakai untuk "menunjuk" (labelling) kelompok atau golongan tertentu. Secara sederhana identitas dipahami sebagai konsep diri untuk memahami siapa diri kita sebenarnya (Martin, J. N. dan Nakayama, 2010). Identitas pada dasarnya merujuk pada pandangan reflektif mengenai diri kita sendiri ataupun persepsi orang lain mengenai diri kita (Ting-Toomey, 1999).

Identitas kultur dapat dipahami dari gaya komunikasi, orientasi budaya, dan makna diri yang dipraktikkan oleh suatu etnik dalam relasi sosial di masyarakat. Pertama, gaya komunikasi adalah perilaku komunikasi dalam menyampaikan pesan baik verbal maupun non verbal. Kedua, Orientasi budaya dalam pandang Hofstede (Samovar, L. A., Porter, R. E. dan McDaniel, 2014) dibagi dalam dua dimensi yaitu budaya individualis dan budaya kolektivis. Ketiga, makna diri (self construal) adalah cara memandang diri mereka dalam relasi dengan orang lain. Seseorang dapat memandang diri mereka terpisah (otonom) dari orang lain atau terkoneksi dengan orang. Self construal (SC) terdiri dari independen dan interdependen. Independen $S C$ adalah pemaknaan diri sebagai kesatuan yang terpisah dari konteks sosial. Seseorang dengan tipe independen $S C$ selalu memandang diri mereka sebagai pribadi unik dan berbeda dari orang lain, dominan menyatakan dirinya sebagai individu yang berdiri sendiri dengan cara mengekspresikan atribusi internalnya seperti kemampuan dan kecerdasannya kepada publik. Sementara interdependen $S C$ adalah pemaknaan diri yang tidak terpisah dari konteks sosial (Markus, H. dan Kitayama, 1991).

Berdasarkan uraian latar belakang tersebut, maka penelitian ini bertujuan untuk menganalisis dan mendeskripsikan identitas etnik Komin dan Amber di Papua dalam praktik komunikasi antarbudaya dalam hal: (1) Gaya komunikasi; Komunikasi konteks rendah vs Komunikasi konteks tinggi; (2) Orientasi budaya; 
budaya kolektivis vs budaya individualis; (3) Konstrual diri: Independen vs Interdependen. Melalui penelitian ini diharapkan menjadi pengetahuan bagi pemerintah maupun masyarakat di Papua dalam membangun relasi antaretnik sehingga tercipta harmonisasi dan kondusif melalui pemahaman gaya komunikasi, orientasi budaya, dan konstrual diri yang melekat dalam diri setiap etnik di Papua.

Penelitian ini menganalisis relasi etnik dalam hubungan antaretnik asli Papua yang terwakili oleh etnik pantai dan pegunungan sementara etnik Amber terwakili oleh etnik Bugis dan etnik Jawa. Karenanya penelitian ini memiliki keterbatasan di mana tidak semua etnik yang ada di Papua dapat terwakili dalam penelitian ini, mengingat keterbatasan waktu, tenaga, dan biaya. Demikian halnya dengan ruang lingkup penelitian dibatasi hanya pada identitas kultur, kekerasan simbolik, in group dan outgroup, dan mindfull komunikasi. Penelitian ini memiliki implikasi pada pentingnya memahami relasi antaretnik di Papua dalam pelaksanaan proses pembangunan di Papua.

\section{LANDASAN KONSEP}

\section{Penelitian Terdahulu}

Leysan Khakimova, Yan Bing Zhang dan Jeffrey A. Hall (2012) melakukan penelitian tentang: Gaya Manajemen Konflik: Peran identitas etnik dan self construal antara Pemuda Pria Arab dan Amerika. Penelitian antarbudaya ini membandingkan persepsi identitas etnik, self construal, dan gaya manajemen konflik laki-laki pemuda Arab dan pemuda lakilaki Amerika. Temuan menunjukkan bahwa orang Arab memiliki identitas etnik lebih kuat dari Amerika. Kedua, Arab lebih mandiri dan saling membutuhkan dibandingkan partisipan Amerika. Perbandingan gaya konflik menunjukkan bahwa orang Amerika menunjukkan ekspresi emosional, mendominasi, dan mengabaikan, sedangkan Arab memilih mengintegrasikan, bantuan pihak ketiga, dan menghindari gaya dari Amerika. Keduanya tidak berbeda dalam preferensi mereka tentang gaya manajemen konflik. Dalam hal hubungan antara identitas etnik, self construal, dan gaya konflik, sedikit perbedaan yang ditemukan antara kedua kelompok budaya. Satu-satunya gaya konflik yang diperkirakan berbeda antara peserta Arab dan Amerika adalah gaya ekspresi emosional (Khakimova, L,.Zhang, Y.B. dan Hall, 2012).

Rahardjo (2005), melakukan penelitian tentang: Mindfulnes dalam Komunikasi Antaretnis (Studi tentang Komunikasi antar etnis Cina dengan etnis Jawa: Kasus Sudiroprajan, Solo). Landasan teoretik dari studi ini adalah genre interpretif, yaitu pemikiran yang berusaha menemukan makna dari suatu tindakan dan teks. Studi ini juga merujuk pada gagasan fenomenologi sebagai basis berpikir. Fenomenologi merupakan studi tentang pengetahuan yang berasal dari kesadaran. Penelitian ini menerapkan prinsip triangulasi dengan mengombinasikan metode kuantitatif (survei) dengan metode kualitatif (fenomenologi). Dalam pelaksanaannya, studi ini menerapkan model triangulasi, desain menggunakan paradigma dominan (interpretif) dan dilengkapi dengan satu komponen kecil dari paradigma alternatif (positivisme). Hasil studi ini memperlihatkan bahwa warga kedua kelompok etnis di wilayah penelitian mampu menciptakan situasi komunikasi yang mindful, karena mereka memiliki kompetensi komunikasi antarbudaya yang memadai, yaitu kemampuan mengintegrasikan motivasi, pengetahuan, dan kecakapan untuk bisa berkomunikasi secara layak, efektif, dan memuaskan.

\section{Gaya Komunikasi (High vs Low Context)}

Konteks komunikasi menurut E.T. Hall (Samovar, L. A., Porter, R. E. dan McDaniel, 2014) adalah informasi suatu kejadian yang tidak dapat dihindarkan berhubungan dengan arti kejadian. 
Konteks merupakan lingkungan yang mengelilingi sesuatu dan membantu memberikan makna pada sesuatu. Dalam berkomunikasi konteks mengelilingi pesan dan memberikan makna pada pesan. Banyak atau sedikitnya konteks yang mengelilingi pesan menyebabkan perbedaan gaya komunikasi. Gaya komunikasi yang relatif memiliki banyak konteks yang mengelilingi pesan dimaknai sebagai komunikasi konteks tinggi sedangkan gaya komunikasi yang relatif memiliki sedikit konteks yang mengelilingi pesan adalah komunikasi konteks rendah.

Gaya komunikasi (communication styles) adalah perilaku komunikasi dalam menyampaikan pesan baik verbal maupun non verbal. Edward T Hall (Mulyana, 2006) membagi gaya komunikasi ke dalam dua konteks, yaitu gaya komunikasi konteks tinggi dan gaya komunikasi konteks rendah. Komunikasi kontekstinggi adalah komunikasi yang bersifat implisit dan ambigu, tidak jelas dan berputar-putar, sehingga menuntut penerima pesan untuk menafsirkannya sendiri. Penyampaian pesan cenderung diawali dengan basa-basi dan teramat sering menggunakan kata-kata kiasan tanpa menyebut inti pesan. Sementara komunikasi konteks rendah adalah komunikasi bersifat langsung (direct communication), lugas, apa adanya, tidak berbelit-belit dan tidak ambigu. Pokok pembicaraan yang ingin disampaikan sangat mudah diterima oleh lawan bicaranya, tanpa harus melakukan penafsiran.

Ciri lain dari komunikasi konteksrendah menurut E.T. Hall (Ting-Toomey, 1999) ditujukan pada pola komunikasi mode lisan langsung (direct verbal mode), kesiapan non verbal (nonverbal immediacy) dan pengirim berorientasi nilai (sender-oriented values). Pengirim bertanggungjawab untuk menyampaikan pesan secara jelas. Sedangkan dalam komunikasi konteks rendah, pembicara diharapkan untuk lebih bertanggungjawab untuk membangun sebuah kejelasan, pesan yang meyakinkan sehingga pendengar dapat membaca sandi (decode) dengan mudah.

Tabel 1

Karakteristik Komunikasi Konteks Rendah dan Tinggi

\begin{tabular}{ll}
\hline \multicolumn{1}{c}{ Konteks Rendah } & \multicolumn{1}{c}{ Konteks Tinggi } \\
\hline Interaksi verbal langsung dan kurang mampu & Interaksi verbal tidak langsung dan lebih mampu \\
membaca ungkapan non verbal; fokus pada kata-kata. & membaca ungkapan non verbal; fokus pada perilaku. \\
Speaker-oriented style (banyak bicara). & Listener-oriented style (banyak mendengar) \\
Mengatakan "tidak" benar-benar dapat diterima dan & Tidak sopan untuk mengatakan "tidak" pada \\
dihargai. & permintaan. \\
Mengandalkan fakta, statistik, dan detail pendukung & Seringkali mengandalkan intuisi atau kepercayaan \\
yang tepat. & ketimbang fakta. \\
\hline
\end{tabular}

Sumber: Edward T. Hall (Baker dan Campbell, 2013).

Tabel 2

Karakteristik individualisme dan kolektivisme

\begin{tabular}{ll}
\multicolumn{1}{c}{ Individualisme } & \multicolumn{1}{c}{ Kolektivisme } \\
\hline Otonomi individual & Kesatuan kelompok dan harmoni \\
Orientasi pada diri sendiri & Orientasi pada kelompok \\
Mengutamakan kepentingan individu & Mengutamakan kepentingan kelompok \\
Unik dan bebas & Peduli terhadap ketergantungan sesama \\
Mengutamakan kehormatan individu & Pemilikan kelompok \\
Keluarga inti & Keluarga luas \\
Pemberian ganjaran kepada individu & berdasarkan \\
kesamaan hak (equility) & Distribusi ganjaran mengutamakan keseimbangan \\
Persaingan & \\
\hline
\end{tabular}

Sumber: Hofstede (Liliweri, 2003). 


\section{Orientasi Budaya (Individu vs Kolektif)}

Individualisme vs kolektivisme atau sering juga diartikan sebagai orientasi pribadi vs orientasi kelompok menjadi salah satu variabel pola dasar yang menentukan tindakan manusia. Individualime atau kolektivisme merupakan variabel kebudayaan yang digunakan untuk menjelaskan perbedaan dan persamaan dalam komunikasi antarbudaya (Gudykunst, 2003).

Orientasi budaya dalam pandang Hofstede (Samovar, L. A., Porter, R. E. dan McDaniel, 2014) dibagi dalam dua dimensi yaitu budaya individualis dan budaya kolektivis. Budaya kolektivis menurut Mills dan Clark (Triandis, 2001) adalah ketergantungan individu dalam kelompok (keluarga, suku, bangsa, dan lain-lain), dengan tujuan mengutamakan kepentingan kelompok, membentuk perilaku mereka terutama atas norma-norma dasar dalam kelompok, dan berperilaku dengan cara komunal. Budaya kolektivis lebih memilih metode penyelesaian konflik yang tidak merusak hubungan, misalnya melakukan mediasi. Sementara budaya individu adalah bersifat otonom dan independen, prioritas untuk tujuan pribadi daripada tujuan kelompok, berperilaku atas dasar sikap mereka daripada norma-norma dalam kelompok.

Pola individualisme (identitas keakuan) memrioritaskan kebutuhan atau nilai pribadi di atas kebutuhan atau nilai kelompok sedangkan kolektivisme (identitas ke-kitaan) memrioritaskan kebutuhan atau nilai kelompok di atas kebutuhan atau nilai individu (West, R. dan Turner, 2007). Andersen, dan kawankawan mengatakan sifat budaya kolektivitas menekankan komunitas, kolaborasi, minat, harmoni, tradisi, fasilitas umum, dan memertahankan harga diri, sedangkan budaya indvidualistis menekankan hak dan kewajiban pribadi, privasi, menyatakan pendapat pribadi, kebebasan, inovasi, dan ekspresi diri (Samovar, L. A., Porter, R. E. dan McDaniel, 2014).

\section{Konstrual Diri (Independen vs Interdependen)}

Self Construal (SC) dikembangkan oleh Markus dan Kitayama yang digunakan untuk menjelaskan perbedaan persepsi atau pemahaman individu dalam memaknai diri. Persepsi atau pemahaman individu ini dilihat dari hubungan yang terjalin antara individu dengan orang lain dan lingkungan. Persepsi atau pemahaman individu tentang makna diri dapat berfungsi sebagai kerangka berpikir, yang akan memengaruhi kognisi, motivasi, pola sosialisasi, interaksi, dan cara individu menempatkan diri di lingkungan. Persepsi atau pemahaman individu tentang makna diri ini juga akan menggambarkan tipe dan karakter individu, serta menjadi pedoman dalam berperilaku.

$S C$ dapat dipahami sebagai cara orang memandang diri mereka dalam relasi dengan orang lain. Seseorang dapat memandang diri mereka terpisah (otonom) dari orang lain atau terkoneksi dengan orang lain (Markus, H. dan Kitayama, 1991). SC menurut Markus dan Kitayama dibagi menjadi dua tipe, yaitu independent $S C$ dan interdependent $S C$

Independent $S C$ adalah pemaknaan diri sebagai kesatuan yang terpisah dari konteks sosial, orang dengan independent $S C$ memandang diri mereka sebagai pribadi unik dan berbeda dari orang lain dengan kata lain bersifat stabil dan otonom dari konteks sosial. Individu dengan independent $S C$ dominan akan menyatakan dirinya sebagai individu yang berdiri sendiri dengan cara mengekspresikan atribusi internalnya seperti kemampuan, kecerdasan, dan lain-lain kepada publik. Independent SC biasanya berkembang di negara yang berorientasi pada budaya individualisme sangat mengutamakan keunikan dan memandang diri sebagai bagian yang terpisah dari orang lain, serta menyatakan dirinya sebagai individu yang berdiri sendiri, dengan cara mengekspresikan atribusi internalnya seperti kemampuan, kecerdasan, dan lainlain kepada publik 
Tabel 3

Karakteristik $S C$ Independen dan $S C$ Interdependen

\begin{tabular}{|c|c|c|}
\hline Komponen & $S C$ Independen & $S C$ Interdependen \\
\hline Definisi & Terpisah dari konteks sosial & Terhubung dengan konteks sosial \\
\hline Struktur & Membatasi, independen, stabil & Fleksibel, berubah-ubah \\
\hline Ciri- ciri penting & $\begin{array}{l}\text { Internal, pribadi (kemampuan pemikiran, } \\
\text { perasaan) }\end{array}$ & $\begin{array}{l}\text { Eksternal, publik (status, peran, } \\
\text { hubungan) }\end{array}$ \\
\hline \multirow[t]{5}{*}{ Tugas } & Menjadi unik & Terlibat, menjadi sesuai \\
\hline & Mengekspresikan diri & Menempati tempat yang tepat \\
\hline & Merealisasikan sifat internal & Menggunakan aksi yang tepat \\
\hline & Mempertimbangkan tujuan sendiri & Mempertimbangkan tujuan orang lain \\
\hline & $\begin{array}{l}\text { Terus terang, "mengatakan apa apa yang } \\
\text { dipikirkan orang }\end{array}$ & $\begin{array}{l}\text { Tidak terus terang, "membaca yang } \\
\text { dipikirkan }\end{array}$ \\
\hline Peran orang lain & $\begin{array}{l}\text { Evaluasi diri: orang lain penting untuk } \\
\text { perbandingan sosial, merendahkan } \\
\text { penilaian }\end{array}$ & $\begin{array}{l}\text { Pendefinisian diri: berhubungan } \\
\text { dengan orang lain dalam konteks } \\
\text { khusus }\end{array}$ \\
\hline Penentu harga diri & $\begin{array}{l}\text { Kemampuan untuk mengekspresikan diri, } \\
\text { membenarkan atibusi diri }\end{array}$ & $\begin{array}{l}\text { Kemampuan untuk menyesuaikan diri, } \\
\text { menahan diri, menjaga harmoni } \\
\text { dengan sosial. }\end{array}$ \\
\hline
\end{tabular}

Sumber: Markus, H. dan Kitayama, 1991.

\section{METODE PENELITIAN}

Penelitian ini dirancang mengunakan paradigma positivistik dalam melakukan analisis hasil penelitian yang dirancang dalam skema penelitian kombinasi (mix method) yaitu penggabungan metode kualitatif dan kuantitatif.

Pengabungan pendekatan dilakukan untuk kepentingan sifat data baik secara kualitatif maupun dengan kuantitatif. Metode kombinasi (Creswell, 2009) digunakan untuk menetralisir atau menghilangkan bias-bias dalam satu metode.

Metode kombinasi Creswell yang digunakan adalah strategi eksploratoris sekuensial yakni eksplorasi data lebih condong pada data dan analisis kualitatif. Strategi ini diterapkan dengan pengumpulan dan analisis data kuantitatif pada tahap pertama kemudian data dieksplorasi melalui analisis data kualitatif pada tahap selanjutnya. Karena data kuantifikasi dalam penelitian ini hanya berfungsi sebagai data pendukung, maka analisisnya tidak bermaksud untuk melakukan uji statistik secara komprehensif sebagaimana prosedur penelitian kuantitaif pada umumnya.

Lokasi penelitian dilakukan di Kota Jayapura, di mana Kota Jayapura sebagai Ibukota Provinsi Papua dengan populasi penduduk antaretnik Komin dan Amber relatif berimbang.

Teknik sampling menggunakan quota sampling dengan jumlah sampel 200 responden yang diambil dari masingmasing etnik 100 responden. Sedangkan data kualitatif dilakukan wawancara mendalam kepada 8 (delapan) partisipan yang masing-masing etnik diwakili oleh 4 (empat) orang. 


\section{HASIL PENELITIAN DAN PEMBAHASAN}

\section{Gaya Komunikasi}

Gaya komunikasi antaretnik di Papua dari hasil penelitian di lapangan menunjukkan bahwa kedua etnik samasama mempraktikkan gaya komunikasi konteks tinggi dan rendah namun dalam proporsi yang berbeda. Etnik Komin cenderung mempraktikkan gaya komunikasi konteks rendah dibandingkan dengan etnik Amber yang cenderung mempraktikkan gaya komunikasi konteks tinggi. Gaya komunikasi konteks rendah yang dipraktikkan etnik Komin tercermin dari gaya komunikasi cenderung kasar, emosional, terbuka, lansung, mendesak, spontan, dan ngotot. Sebaliknya etnik Amber memiliki gaya komunikasi konteks tinggi yaitu nada suara pelan, tenang, mengalah, basa-basi, sungkan, menghargai orang lain, dan lainnya. Deskripsi gaya komunikasi kedua etnik dapat dilihat pada Gambar 1.

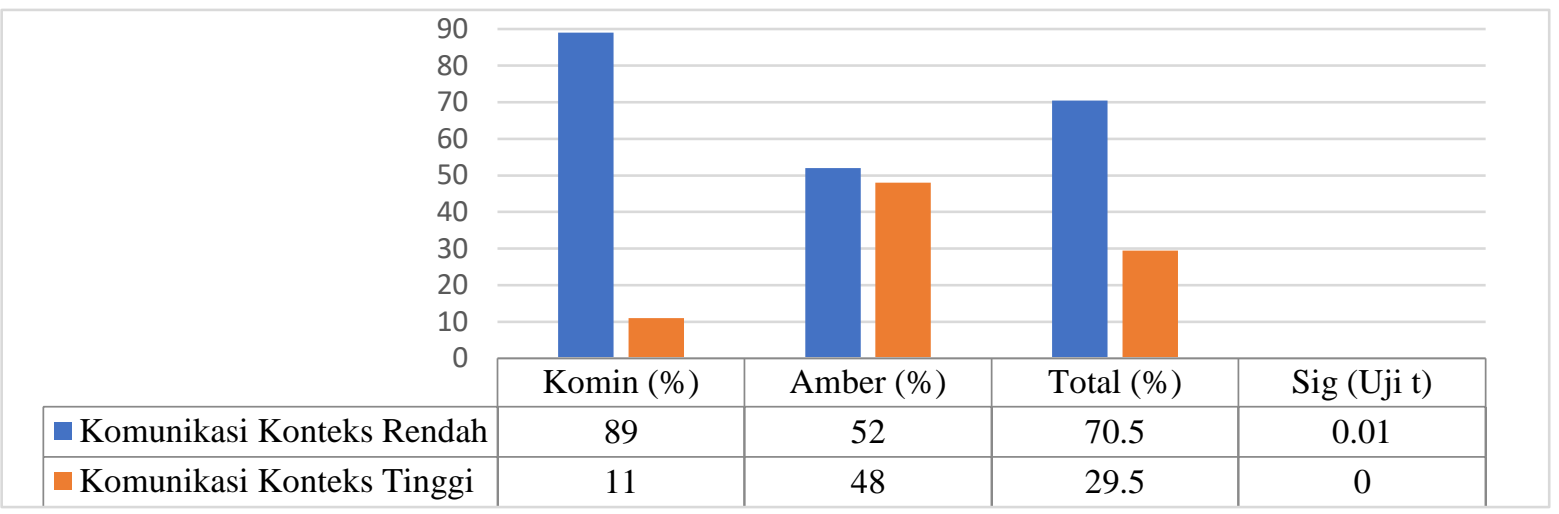

Ket, $\mathrm{n}$ Komin $=100, \mathrm{n}$ Amber $=100$ Total $=200 *$ nyata pada $\mathrm{p}<0,05$ dan $* *$ sangat nyata pada $\mathrm{p}<0,01$ Sumber : data primer (2015)

Gambar 1. Deskripsi dan Uji beda Responden berdasarkan Gaya Komunikasi

Tabel 4

Indikator Gaya Komunikasi Etnik Komin-Amber di Papua

\begin{tabular}{|c|c|c|c|c|}
\hline \multirow[t]{2}{*}{ Indikator gaya komunikasi } & \multicolumn{2}{|c|}{ Komin } & \multicolumn{2}{|c|}{ Amber } \\
\hline & $\mathbf{r}(\%)$ & $\mathrm{t}(\%)$ & $\mathbf{r}(\%)$ & $\mathrm{t}(\%)$ \\
\hline - Suara keras & 79 & & 43 & \\
\hline - Suara pelan & & 21 & & 57 \\
\hline - Ucapan Kasar & 51 & & 36 & \\
\hline - Ucapan Halus & & 49 & & 62 \\
\hline - Emosional & 53 & & 18 & \\
\hline - Tenang & & 47 & & 82 \\
\hline - Terbuka & 69 & & 54 & \\
\hline - Tertutup & & 31 & & 46 \\
\hline - Seadanya/langsung & 90 & & 47 & \\
\hline - Puitis/basa-basi & & 10 & & 53 \\
\hline - Mendesak/represif & 70 & & 23 & \\
\hline - Menahan/persuasif & & 30 & & 77 \\
\hline - Spontan & 90 & & 58 & \\
\hline - Sungkan/segan & & 10 & & 42 \\
\hline - Ngotot & 90 & & 55 & \\
\hline - Mengalah & & 10 & & 45 \\
\hline - Sejujurnya & 90 & & 55 & \\
\hline - Menghindari Kata tidak & & 10 & & 45 \\
\hline
\end{tabular}

Ket $: \mathrm{r}=$ rendah, $\mathrm{t}=$ tinggi

Sumber : data primer (2015) 
Praktik komunikasi antara etnik Komin dan Amber pada konteks komunikasi berbeda nyata (0.01) dengan signifikansi $<0,01$. Kondisi ini menjelaskan bahwa, kedua etnik memiliki perbedaan dalam gaya komunikasi. Hal ini disebabkan oleh latar belakang budaya, norma atau nilai, situasi, dan kondisi lingkungan dalam relasi sosial masyarakat. Etnik Komin cenderung pada konteks rendah dibanding etnik Amber sebaliknya komunikasi konteks tinggi cenderung dipraktikkan etnik Amber dibanding etnik Komin. Uraian gaya komunikasi kedua etnik dapat tercermin dalam indikator Tabel 4.

\section{Deskripsi Struktural dan Struktural}

Hasil konstruksi penelitian di lapangan menjelasan bahwa etnik Amber dalam suasana dialog yang tenang, santai penuh canda, berada pada komunikasi konteks rendah, namun seketika dapat berubah pada konteks tinggi dalam situasi dialog yang berpotensi munculnya ketegangan dan menimbulkan perdebatan. Komunikasi konteks tinggi umumnya dipraktikkan jika berinteraksi dengan etnik Komin, sebaliknya jika berada dalam kelompoknya yang dianggap sudah familier maka dia cenderung masuk dalam praktik konteks rendah.

Hasil wawancara (data kualitatif) dengan narasumber dapat digambarkan bahwa partisipan dari etnik Amber menceritakan pengalaman mereka bagaimana gaya komunikasi yang dipraktikkan ketika berinteraksi dengan etnik Komin. Gaya komunikasi yang dipraktikkan seperti partispan MA cenderung berada pada konteks tinggi apabila berhadapan dengan etnik Komin, walaupun sebenarnya MA mengakui bahwa pada dasarnya gaya komunikasi mereka hampir mirip dengan cara-cara yang dilakukan oleh etnik Komin yang cenderung apa adanya. Berikut penuturan partisipan MA (67 tahun), yang beretnik Bugis/Makassar.

"Setiap hari saya bertemu dan berkomunikasi dengan orang Papua. Cara bicara mereka (orang Papua) ceplas-ceplos, emosi, dan meledak-ledak. Suara keras bahkan kedengarannya kasar beda dengan pendatang cenderung pelan dengan intonasi rendah atau sedang. Sebagian besar orang Papua kalau bicara memang seperti itu. Awalnya kaget-kaget, saya kira mereka marah padahal tidak. Lama-lama saya terbiasa dengan gaya komunikasi mereka," (Jayapura, September 2015).

Pengalaman lainnya dituturkan oleh partispan AS, yang melihat etnik Papua dari pegunungan dan pantai sedikit berbeda dalam praktik komunikasinya. Menurutnya, etnik pegunungan kecenderungannya pendiam (tidak banyak bicara) dan lebih mengutamakan simbolisasi bahasa tubuh dalam mengungkapkan ekpresinya, sedangkan etnik pantai lebih terbuka dalam menyampaikan pesannya secara oral. Berikut penuturan AS (65 tahun), yang beretnik Jawa.

"Orang gunung dan pantai itu beda. Orang gunung cenderung tertutup dan tidak banyak bicara. Mereka lebih banyak diam dan lebih mengandalkan gerak-gerik, semacam kode-kode begitulah. Berbeda dengan orang pantai yang lebih terbuka dan bicaranya panjang lebar. Walaupun cara menyampaikan beda, tapi keduanya terbuka dan gampang dipahami maksudnya karena meraka apa adanya kalau bicara," (Jayapura, September 2015).

Pada umumnya, gaya komunikasi yang dipraktikkan MA ada AS, juga dialami dan dipraktikkan oleh partisipan etnik Amber lainnya. Praktik komunikasi konteks tinggi terpaksa dilakukan oleh etnik Amber bukan semata-mata untuk menghormati tetapi lebih dikarenakan menghindari risiko konflik dengan etnik Papua. Tutur kata yang lembut, intonasi suara yang sengaja dipelankan dan diatur sedemikian rupa, semuanya itu lebih dari sekedar kesadaran mereka sebagai etnik pendatang.

Gaya komunikasi etnik Komin sangat berbeda dengan etnik Amber. Etnik Komin cenderung masuk dalam praktik 
komunikasi konteks rendah, baik secara pribadi maupun ketika berinteraksi dengan etnik Amber.

Hal ini tergambar dari praktik komunikasi yang dilakukan oleh partisipan seperti suara yang keras, tidak bertele-tele, lantang, dan berkata apa adanya. Etnik Komin memunyai pemahaman gaya komunikasi tentang dirinya sendiri dalam berinteraksi dengan kelompoknya (ingroup) maupun dengan etnik Amber (outgroup). Partisipan ON (42 tahun) menjelaskan tentang gambaran dirinya ketika berinteraksi dengan sesama mereka maupun dengan etnik lainnya

"Orang Papua itu kalau bicara tidak dibuat-buat. Kalau tidak akan bilang tidak suka demikian juga kalau suka akan bilang suka. Memangnya kenapakah kalau kita terus terang, kan lebih bagus toh, daripada kita sembunyi-sembunyi. Orang tidak tahu kita pu mau macam dorang pendatang suka basa-basi. Mau bilang tra sopankah, terserah dorang toh, dia pu urusan yang penting kita su kasi tau" (Jayapura, Agustus 2015).

Etnik Komin menceritakan pula bagaimana pengalaman mereka ketika berinteraksi dengan Amber. Sebagian besar partisipan etnik Komin setuju dan beranggapan bahwa gaya komunikasi etnik Amber cenderung menggunakan praktik komunikasi konteks tinggi. Praktik komunikasi konteks tinggi yang dimaksud etnik Komin dicirikan dengan praktik komunikasi etnik Amber yang berbelitbelit, basa-basi, kaku, suara yang dilemahkan, dan terkesan mencari aman. Praktik komunikasi yang berbeda ini, terkadang mengalami sedikit kendala sehingga mengakibatkan suasana keakraban terlihat kaku, namun perbedaan ini pula memunyai sisi positif dalam meminimalisir konflik.

"Orang pendatang kalau bicara dengan torang memang kelihatan sopan dan ramah-ramah. Mereka tidak banyak bicara, dorang tenang, lebih banyak diam dan mendengar. Saya tau dorang pendatang sebenarnya tidak seperti itu, karena mereka kalau sesama pendatang juga sering ribut. Mungkin dorang pendatang tidak mau ribut dengan orang Papua, jadi mereka seperti itu sudah" (Jayapura, Agustus 2015).

Hasil konstruksi dari pengalaman etnik Komin-Amber di atas memberikan pemahaman bahwa kedua etnik dalam membangun relasi dengan out-group mereka sangat berbeda dalam hal gaya komunikasi.

Etnik Komin cenderung mempraktikkan gaya komunikasi konteks rendah yang menampilkan gaya komunikasi apa adanya, terbuka dan pesan yang disampaikan mudah dipahami, sedangkan etnik Amber cenderung mempraktikkan gaya komunikasi konteks rendah yang menampilkan gaya komunikasi yang basa-basi, tidak lepas, dan maksud pesan yang disampaikan secara tersirat.

\section{Orientasi Budaya (Individualis vs Kolektivis)}

Orientasi budaya, budaya kolektivis cenderung dilakukan oleh etnik Komin, sedangkan orientasi budaya individual cenderung dilakukan oleh etnik Amber.

Hasil penelitian menjelaskan bahwa, orientasi budaya kolektivis yang dipraktikkan etnik Komin tercermin dari budaya yang masih dipertahankan hingga saat ini, seperti sikap hormat kepada pemimpin atau kepala suku, norma atau nilai, aturan hukum adat, solidaritas kesukuan, jaringan kekerabatan di antara sesama angota masyarakat adat. Budaya Papua yang kolektif menjadi salah satu faktor mengapa orang Papua sulit untuk menerapkan hidup secara individual. Sedangkan orientasi budaya etnik Amber yang individual disebabkan oleh situasi dan kondisi lingkungan di mana sebagai pendatang mereka harus mampu bertahan dalam relasi soial masyarkat. Hal ini tercermin dari praktik budaya yang menonjolkan kepentingan pribadi, menonjolkan atribusi diri, dan tidak bergantung dengan orang lain atau kelompoknya. 
Tabel 5

Indikator Orientasi Budaya Etnik Komin dan Amber di Papua

\begin{tabular}{|c|c|c|c|c|}
\hline \multirow{2}{*}{ Indikator } & \multicolumn{2}{|c|}{ Komin } & \multicolumn{2}{|c|}{ Amber } \\
\hline & i (\%) & $\mathrm{k}(\%)$ & i (\%) & i (\%) \\
\hline Patuh pada diri sendiri & 9 & & 47 & \\
\hline Patuh pada pimpinan & & 91 & & 53 \\
\hline Mengedepankan logika & 48 & & 44 & \\
\hline Mengedepankan Perasaan & & 52 & & 56 \\
\hline Frontal & 74 & & 19 & \\
\hline Kompromi & & 26 & & 81 \\
\hline Keyakinan pribadi & 6 & & 28 & \\
\hline Keyakinan kelompok & & 94 & & 72 \\
\hline Kepentingan pribadi & 43 & & 52 & \\
\hline Kepentingan bersama & & 57 & & 48 \\
\hline Suara terbanyak & 23 & & 42 & \\
\hline Musyawarah dan Mufakat & & 77 & & 58 \\
\hline Saling percaya (Menjaga keharmonisan) & 76 & & 51 & \\
\hline Curiga (kewaspadaan) & & 24 & & 49 \\
\hline Pamrih (kepentingan) & 16 & & 33 & \\
\hline Toleransi (solidaritas) & & 84 & & 67 \\
\hline Tanggung jawab individu & 31 & & 62 & \\
\hline Senasib sepenanggungan & & 69 & & 38 \\
\hline Pantang menyerah & 74 & & 43 & \\
\hline Menghindari konflik & & 26 & & 57 \\
\hline Sejajar & 24 & & 41 & \\
\hline Sapaan menentukan status & & 76 & & 59 \\
\hline
\end{tabular}

Ket : I = Individu, $\mathrm{K}$ = Kolektif

Sumber: data primer (2015)

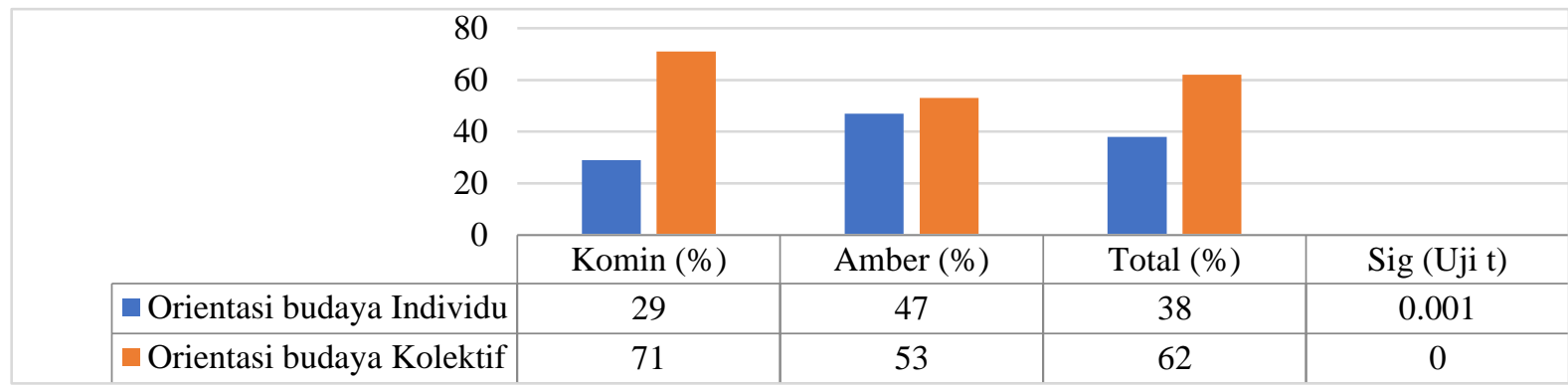

Ket, $\mathrm{n}$ Komin $=100, \mathrm{n}$ Amber $=100$ Total $=200 *$ nyata pada $\mathrm{p}<0,05$ dan $* *$ sangat nyata pada $\mathrm{p}<0,01$ Sumber : data primer (2015)

Gambar 2. Deskripsi dan hasil uji beda Etnik Komin-Amber berdasarkan Orientasi Budaya

Orientasi budaya antara etnik Komin dan Amber berbeda nyata $(0,01)$ pada siginifikansi $<0,01$ Dalam pelaksanaannya, orientasi budaya kedua etnik cenderung kolektif, namun secara keseluruhan partisipan etnik Komin cenderung berorientasi budaya kolektif (71 persen) dibanding partisipan etnik Amber (53 persen).

Untuk lebih jelasnya, perbedaan orientasi budaya kedua etnik dapat dilihat dalam tabel 5.

\section{Deskripsi Tekstural dan Struktural}

Etnik Komin maupun etnik Amber tidak lepas dari dua nilai budaya individu dan kolektif. Kedua etnik sama-sama menerapkan sifat individualnya dan kolektifnya. Orientasi budaya individu dan kolektif selalu berada di antara keduanya, terkadang sisi individualnya yang dominan terkadang pula sisi kolektifnya yang tinggi dalam menyikapi setiap persoalan pada situasi yang berbeda. Secara umum orientasi budaya pada etnik Komin dan 
Amber dapat diinterpretasikan masuk pada orientasi budaya kolektif. Budaya kolektif dicirikan oleh kepentingan bersama, solidaritas sosial yang tinggi, senasib sepenangungan, dan rasa empati terhadap individu lainnya. Sebagian besar partisipan mengakui bahwa kebiasaan-kebiasaan yang dipraktikkan sehari-hari tidak terlepas dari kebiasaan yang dilakukan berdasarkan tradisi atau adat istiadat yang dilakukan oleh orang tua atau kelompoknya.

Orientasi budaya pada etnik Komin dan Amber dapat diinterpretasikan masuk pada orientasi budaya kolektif. Budaya kolektif dicirikan oleh lebih dominannya perasaan senasib sepenanggungan, kepentingan bersama, dan rasa empati yang begitu besar terhadap individu lainnya. Sebagian besar partisipan mengakui bahwa kebiasaan-kebiasaan yang dipraktikkan sehari-hari tidak terlepas dari kebiasaan yang didapatkan sebelumnya dari orang tua atau kelompoknya.

Hasil wawancara (data kualitatif) dapat dijelaskan bahwa, partisipan etnik Amber dari suku Jawa misalnya melestarikan budaya dengan membiasakan diri menggunakan percakapan bahasa Jawa dalam lingkungan keluarga mereka seharihari.

Etnik Amber-Jawa beranggapan bahwa menggunakan bahasa Jawa berarti menunjukkan identitas mereka sekaligus menunjukkan budaya mereka yang berorientasi budaya kolektif. Dalam bahasa Jawa dikenal dengan istilah bahasa Jawa ngoko (bahasa kasar) dan kromo inggil (bahasa halus). Bahasa Jawa ngoko dipakai untuk orang yang sudah dikenal akrab, orang yang lebih muda usianya serta lebih rendah tingkatannya atau status sosialnya. Bahasa Jawa kromo inggil digunakan untuk berbicara dengan orang yang belum dikenal tetapi yang sebaya atau derajat dan orang yang umurnya lebih tua atau status sosialnya lebih tinggi. Etnik Amber-Jawa harus memperhatikan dan membeda-bedakan keadaan orang yang diajak bicara atau yang sedang dibicarakan, berdasarkan usia ataupun status sosialnya.
Berikut ini penuturan partsipan AS (67 tahun) dari etnik Jawa.

"Di rumah, saya biasakan keluarga terutama istri dan anak-anak menggunakan bahasa Jawa. Saya melakukan ini supaya anak-anak tidak lupa dengan bahasanya sendiri. karena di sekolah dan pergaulan mereka sehari-hari tidak lagi menggunakan bahasa daerahnya. Apalagi di sini banyak suku, tidak mungkin menggunakan bahasa Jawa sebagai percakapan sehari-hari" (Jayapura, September 2015).

Budaya kolektif etnik Amber dari suku Bugis (Makasar), tidak jauh berbeda dengan praktik kolektif yang dilakukan etnik Amber-Jawa. Dalam tradisi Bugis ada istilah yang dikenal dengan budaya tudang sipulung atau duduk bersama. Tradisi duduk bersama ini juga dilakukan oleh etnik Amber-Bugis di Papua. Forum warga lewat tudang sipulung ini membahas apa saja yang terkait dengan persoalanpersoalan yang menyangkut tentang kehidupan warga etnik Bugis di Papua.

Sebagai pribumi, etnik Papua memperlihatakan budaya kolektivitasnya melalui solidaritas dan ikatan sosial yang tinggi dengan dilandasi oleh kesamaan ras dan pengalaman masa lalu (warisan budaya). Etnik Komin membangun hubungan dalam kelompok kekerabatan dengan mengutamakan kepentingan kelompok dari pada kepentingan individu. Sebagian besar etnik Komin beranggapan bahwa untuk bertahan hidup, mereka bergantung pada kelompoknya dan bukan pada diri sendiri. Pemahaman ini menimbulkan rasa aman pada diri individu anggota kelompok karena akan selalu dibantu pada waktu mereka mengalami kesulitan.

"Dari dulu kami hidup secara berkelompok. Makanya, suku dan bahasa di Papua itu banyak sekali. Hampir setiap kampung di Papua ini memiliki bahasa sendiri-sendiri. Ikatan persaudaraan dalam satu suku sangat dekat." (September, 2015).

Penuturan partisipan dari Etnik Komin-Amber, jelas memperlihatkan 
bahwa orientasi budaya kolektivitas jauh lebih baik mereka praktikkan dibanding dengan budaya individu. Nilai-nilai kolektif menurut mereka, telah mengajarkan adanya rasa kebersamaan dan solidaritas yang tinggi. Namun demikian, mereka juga menyadari bahwa budaya kolektif yang dipraktikkan selama ini, secara tidak langsung memberi rasa ketergantungan yang tinggi sehingga sangat susah berkembang secara individu.

Walaupun praktik budaya kolektif lebih dominan, bukan berarti tidak ada partisipan yang berorientasi individu. Budaya individu tidak hanya dipraktikkan oleh partisipan yang memang kecenderungannya berorientasi individu, tetapi dipraktikkan juga oleh partisipan yang berorientasi kolektif.

Budaya individu biasanya ditandai dalam diri individu atau kelompok dengan ciri kemandirian, tidak tergantung kepada individu atau kelompok lainnya, mengedepankan logika ketimbang perasaan, dan keterlibatan dalam kelompok sosial masyarakat sangat jarang.

Praktik individu biasanya dipraktikkan oleh partisipan dalam situasi atau kondisi tertentu. Bagi sebagian partisipan, budaya individu dianggap sebagai kebiasaan-kebiasaan yang tidak lazim bagi dirinya.

\section{Self Construal (Independen vs Interdependen)}

Self Construal (SC) etnik Komin dan Amber di Papua dari hasil penelitian di lapangan menunjukkan bahwa kedua etnik mempraktikkan independen $S C$ dan interdependen $S C$. Etnik Komin cenderung mempraktikkan interdependen $S C$ dibanding etnik Amber yang cenderung independen $S C$. Interdependen $S C$ etnik Komin dan Amber tercermin dari cara memaknai dirinya sendiri dan bagaimana memaknai dirinya dengan orang lain. Etnik Amber umumnya beranggapan bahwa dirinya tidak terlepas dari konteks sosial, dibentuk oleh pandangan kelompok, ikatan persaudaraan yang tinggi serta rela mengorbakan kepentingan dirinya untuk kepentingan kelompoknya. Sedangkan etnik Amber cenderung memaknai dirinya sebagai orang yang bebas, percaya dengan kemampuan pribadi serta menonjolkan atribusi yang dimiliki.

Praktik Self Construal kedua etnik berbeda nyata $(0,00)$ pada siginifikansi < 0,01. Etnik Amber cenderung independen $S C$, sebaliknya etnik Komin cenderung menerapkan interdependen $S C$. Walaupun etnik Amber cenderung mempraktikkan independen $S C$ (51 persen), namun secara keseluruhan praktik $S C$ kedua etnik masih dominan mempraktikkan interdependen $S C$ (62,5 persen). Untuk lebih jelasnya, praktik $S C$ kedua etnik dapat dilihat dalam Tabel 6.

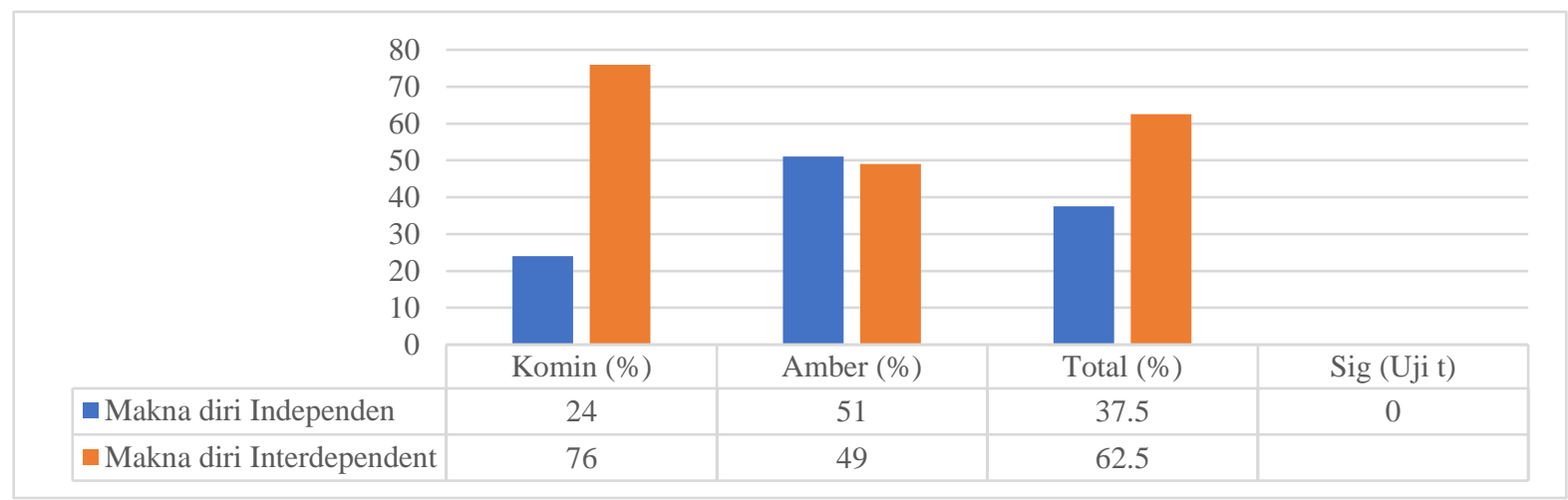

Ket, $\mathrm{n}$ Komin $=100, \mathrm{n}$ Amber $=100$ Total $=200 *$ nyata pada $\mathrm{p}<0,05$ dan $* *$ sangat nyata pada $\mathrm{p}<0,01$ Sumber : data primer (2015)

Gambar 3. Deskripsi dan hasil uji beda Etnik Komin dan Amber berdasarkan Self Construal 
Tabel 6

Indikator Self Construal Etnik Komin-Amber di Papua

\begin{tabular}{|c|c|c|c|c|}
\hline Indikator & & $\operatorname{nin}$ & & ber \\
\hline & Id \% & It \% & Id \% & It \% \\
\hline - Saya terpisah dari konteks sosial & 24 & & 32 & \\
\hline - Saya bagian dari konteks social & & 76 & & 68 \\
\hline - Saya bersifat stabil atau bebas berpendapat & 34 & & 52 & \\
\hline - Saya dibentuk oleh pandangan kelompok & & 66 & & 48 \\
\hline - Bersikukuh (percaya kemampuan pribadi) & 59 & & 55 & \\
\hline - Fleksibel (menyesuaikan) & & 41 & & 45 \\
\hline - Saya menonjolkan atribusi (menunjukkan kecerdasan) & 46 & & 51 & \\
\hline - Merendah (kemampuan diakui orang lain) & & 54 & & 49 \\
\hline - Panggung depan (front stage) & 67 & & 48 & \\
\hline - Panggung belakang (back stage) & & 33 & & 52 \\
\hline - Bertindak sebagai orang yang bebas dan merdeka. & 61 & & 51 & \\
\hline - Saya menghormati keputusan orang lain & & 39 & & 49 \\
\hline - Saya kurang peduli terhadap keinginan orang lain & 47 & & 57 & \\
\hline - Saya peka terhadap keinginan orang lain & & 53 & & 43 \\
\hline - Saya berusaha untuk tidak tergantung pada orang lain & 49 & & 59 & \\
\hline $\begin{array}{l}\text { - Hubungan saya dengan orang lain lebih dari } \\
\text { persaudaraan }\end{array}$ & & 51 & & 41 \\
\hline - Saya puas dengan pencapaian pribadi & 37 & & 64 & \\
\hline Iasan saya tergantung pada kepuasan or & & 63 & & 36 \\
\hline - Saya tidak mau ambil pusing dengan urusan orang lain & 29 & & 47 & \\
\hline & & $\pi 1$ & & 53 \\
\hline
\end{tabular}

Ket $:$ Id $=$ Independen, It $=$ Interdependen

Sumber: data primer (2015)

\section{Deskripsi Tekstural dan Struktural}

Hasil konstruksi dari fenomena di lapangan mempertegas bahwa etnik Amber cenderung berada dalam praktik independen SC. Etnik Amber cenderung memaknai diri sebagai kesatuan yang terpisah dari konteks sosial dan memandang diri mereka sebagai pribadi yang unik dan berbeda dari orang lain. Sebagai individu yang berdiri sendiri, dia mengekspresikan atribusi internalnya seperti kemampuan, kecerdasan, dan lainlain kepada publik. Berbeda dengan etnik Komin yang cenderung mempraktikkan interdependen $S C$. Sebagian besar individu etnik Komin memandang dirinya sebagai bagian dari kelompok. Norma penting bagi interdependen $S C$ seperti mempertahankan keharmonisan kelompok juga sangat terlihat dipraktikkan etnik Komin.

Hasil wawancara (data kualitatif) di lapangan menjelaskan bahwa, praktik independen $S C$ yang dilakukan etnik Amber tidak terlepas dari keberadaan mereka sebagai etnik perantau di Papua. Padahal menurut sebagian besar partisipan bahwa sebelum merantau ke Papua mereka cenderung mempraktikkan interdependen $S C$. Partispan etnik Amber dari suku Jawa misalnya sedikit mengubah penampilan (karakter) asli mereka dari pribadi yang cenderung mengalah menjadi pribadi yang ngotot. Mereka juga lebih berani mengekspresikan dirinya untuk meyampaikan perasaannya secara langsung (front stage) dibanding pada saat sebelum 
mereka ke Papua yang cenderung mengekspresikan dirinya tertutup (back stage). Berikut ini penuturan partisipan AS (67 tahun) dari etnik Jawa.

"Saya merasa banyak sekali berubah setelah saya di sini (Papua). Dulu, sebelum saya merantau ke sini saya orangnya penakut, tapi setelah di sini kok saya lebih berani. Saya juga heran kenapa bisa seperti itu, mungkin karena lingkungan di sini sehingga membuat nyali kita lebih berani" (Jayapura, September 2015).

Independen $S C$ juga dipraktikkan partisipan dari suku Jawa lainnya. Penuturan partisan SR (52 tahun) mengatakan bahwa dirinya sudah tidak terlalu peduli dengan urusan orang lain. Dia lebih fokus pada kepentingan dirinya sendiri.

"Hidup di sini harus lebih fokus pada kepentingan kita sendiri. Jangan terlalu ambil pusing dengan urusan orang lain, pikirkan saja diri kita sendiri. Lagian kita tidak terlalu kenal orang-orang yang ada di sini, jadi, cuek saja yang penting hidup anak istri terjamin" (Jayapura, September 2015).

Independen $S C$ dari suku Bugis tidak jauh berbeda dengan praktik independen $S C$ dari suku Jawa. MA (67 Tahun) yang sudah lama tinggal di Papua menuturkan pengalaman sebagai berikut.

"Saya sudah lama di Papua dan berinteraksi dengan berbagai suku di sini. Mau tidak mau kita harus menyesuaikan dengan kondisi di sini. Kita harus lebih mandiri dan tidak tergantung sama orang lain apalagi kita sebagai perantau di sini. Saya juga tergabung dalam komunitas tapi hanya sekedar untuk silaturahmi" (Jayapura, September 2015).

Praktik $S C$ etnik Komin berbeda dengan etnik Amber. Sebagai pribumi SC mereka tidak terpengaruh oleh kehadiran etnik Amber. Etnik Komin dalam kesehariannya cenderung tetap mempraktikkan interdependen $S C$. Etnik Komin memperlihatkan interdependen $S C$ dengan ketergantungan mereka terhadap pandangan dan arahan dari kelompoknya. Berikut penturan partisipan ON (45 tahun).

"Kami bertindak sesuai dengan aturan suku kami. Arahan atau perintah dari kepala suku harus diikuti. Kami tidak bisa bertindak begitu saja, apalagi menentang perintah dari kepala suku. Kami saling membantu dan menghargai. Ada yang minta bantaun kita bantu, tidak mungkin kami tolak, karena kalau kami butuh mereka juga pasti membantu" (Jayapura, Agustus 2015).

Interdependen $S C$ yang umumnya dilakukan partisipan etnik Komin karena mereka beranggapan bahwa ketergantungan dalam satu kelompok yang dilakukan selama ini jauh lebih baik dibanding hidup terpisah dari kelompok. Masyarakat Papua adalah masyarakat yang sangat kental dengan nilai-nilai adat, menjunjung tinggi aturan adat yang berlaku di masyarakat. Interdependen $S C$ dianggap lebih dekat nilai-nilai budaya mereka sedangkan independen $S C$ dianggap dapat merusak nilai budaya mereka.

\section{PENUTUP}

\section{Simpulan}

Etnik

Komin

cenderung mempraktikkan gaya komunikasi konteks rendah dibanding komunikasi konteks tinggi. Pada orientasi budaya etnik Komin justru cenderung masuk dalam kategori budaya kolektivis dan interdependen $S C$. Gaya komunikasi etnik Komin dalam menyampaikan pesan dikenal lugas, ceplasceplos, langsung ke inti pembicaraan serta terkesan bersuara keras menjurus kasar. Namun demikian praktik budaya seperti menghormati pemimpin (kepala suku), sapaan menentukan status, taat pada adat istiadat, dan tetap mengedepankan keyakinan kelompoknya. Dalam memaknai dirinya, etnik Komin juga cenderung menganggap dirinya masih bagian dari konteks sosial karena itu praktik seperti gotong royong, senasib sepenanggunggan, mengutamakan kepentingan kelompok, dan 
hidup kebersamaan masih dipelihara dan dipertahankan hingga saat ini. Nilai sosial yang memiliki nilai lebih tinggi dibanding nilai ekonomi menjadi perekat bagi etnik komin dalam memaknai relasi sosial dalam kelompok maupun di luar kelompok.

Etnik Amber dalam kesehariannya cenderung mempraktikkan gaya komunikasi konteks tinggi. Namun demikian gaya komunikasi ini tidak diikuti pada orientasi budaya dan $S C$ mereka yang justru cenderung masuk pada budaya individualis dan independen $S C$. Budaya individu dan independen $S C$ dilakukan karena posisi mereka sebagai etnik perantau. Etnik Amber menyampaikan pesan secara berbelit-belit (sedikit puitis) disertai penggunaan simbol, kiasan, dan kata-kata yang diperhalus. Penyampaian pesan selalu diawali dengan kata-kata pembuka yang cenderung mengarah ke basa-basi dalam rangka menjaga perasaan lawan bicara. Praktik budaya seperti menghormati pemimpin, sapaan menentukan status, taat pada adat istiadat, dan mengedepankan keyakinan kelompok tidak lagi diproritaskan. Dalam memaknai dirinya, etnik Amber juga cenderung menganggap dirinya sudah terpisah dari konteks sosial tercermin dari praktik menonjolkan diri, kurang peduli dengan lingkungan cenderung dipraktikkan dalam kehidupan mereka sehari-hari.

Kecenderungan praktik identitas etnik Komin dan Amber ini tidak terlepas dari warisan budaya yang mereka pahami secara turun temurun. Pengalaman yang didapatkan dari keluarga dan lingkungannya di masa lalu, dijadikan pegangan atau standar dalam membangun relasi hingga saat ini. Praktik relasi identitas etnik Komin-Amber dalam bentuk gaya komunikasi, orientasi budaya, dan Self Construal (SC) hanya dipraktikkan dalam kelompok atau etnik mereka masingmasing. Praktik relasi identitas ini akan berubah atau tidak berlaku ketika berhadapan dengan etnik lainnya.

\section{Saran}

Relasi antaretnik akan berjalan dengan baik di Papua manakala pihakpihak yang berbeda secara kultur saling mengetahui dan memahami persamaan dan perbedaannya. Pemahaman atas kesamaan identitas yang mereka miliki akan memunculkan perasaan yang sama sehingga tercipta harmonisasi serta hubungan timbal balik yang menguntungkan di antara mereka. Sebaliknya pemahaman terhadap batasanbatasan out-group nya, akan menghindari atau meminimalisir terjadinya ketidakharmonisan sebagai akar perpecahan atau konflik yang berujung pada tindakan yang menganggu stabilitas kehidupan sosial masyarakat di Papua. Pentingnya pemahaman relasi antaretnik dapat menjadi masukan bagi pemerintah dalam menerapkan berbagai kebijakan yang berkaitan dengan program-program pembangunan masyarakat.

\section{DAFTAR PUSTAKA}

C, B. \& M, C. (2013) Context Matters: An Ethiopian Case Study. U.S. or Canada: Center for Creative Leadership.

Creswell, J.W. (2009) Research Design: Qualitative, Quantitative, and Mixed Methods Approaches. 3rd edition. SAGE Publications.

Gudykunst, W.B. (2003) Cross Cultural and Intercultural Communication. Thousand Oaks, California, Sage Publications, Inc.

Khakimova, L,.Zhang, Y.B. dan Hall, J.. (2012) Conflict Management Styles: The Role of Ethnic Identity and Self-Constructrual among Young Male Arabs and Americans. Journal of Intercultural Communication Research. 41:1, 37-57.

Liliweri, A. (2003) Makna Budaya dalam Komunikasi Antarbudaya. Yogyakarta, LKiS Pelangi Aksara.

Markus, H. dan Kitayama, S. (1991) Culture and the Self: Implications for Cognition, Emotion and Motivation. Psycological Review. 98, 224-253.

Martin, J. N. dan Nakayama, T.K. (2010) Intercultural Communication in Contexts. 
5th edition. New York, McGraw-Hill.

Mulyana, D. (2006) Pengantar Ilmu Komunikasi. Bandung, PT. Remaja Rosdakarya.

Rahardjo, T. (2005) Menghargai Perbedaan Kultural: Mindfulness dalam Komunikasi Antaretnis. Yogyakarta, Pustaka Pelajar.

Samovar, L. A., Porter, R. E. dan McDaniel, E.R. (2014) Communication Between Cultures. 7th edition. Jakarta, Salemba Humanika.

Sewa, T.F.. (2002) Pola Komunikasi Antara Etnis Asli dengan Etnis Pendatang. In: Studi Komunikasi Antarbudaya etnis Ende, Lio dengan etnis Cina dan Padang di Kota Ende Flores. 2002 Jakarta, Universitas Indonesia. p.

Ting-Toomey, S. (1999) Communicating Across Cultures. New York, The Guilford Press.

Triandis, H. (2001) Indivudualism Collecttivism and Personality. Journal of Personality. 69 (6), 907-924.

West, R. dan Turner, L.H. (2007) Teori
Komunikasi ; Analisis dan Aplikasi. 3rd edition. Jakarta, Salemba Humanika. 